\title{
Growth of Chrysanthemum at Low, Relatively Steady Nutrient Levels in a Commercial-style Substrate
}

\author{
Kimberly A. Williams ${ }^{1}$ and Paul V. Nelson ${ }^{2}$ \\ Department of Horticultural Science, North Carolina State University, \\ Raleigh, NC 276957609
}

Additional index words. Chrysanthemum $\times$ morifolium, Dendranthema $\times$ grandiflorum, plant nutrition, $\mathrm{N}$, root media, steady-state uptake

\begin{abstract}
Nutrient solution with a molar ratio of $10 \mathrm{~N}: 1 \mathrm{P}: 3 \mathrm{~K}$ was applied in scheduled intervals at rates of $0.5,1,4$, or $20 \mathrm{~mm} \mathrm{~N}\left(\mathrm{NO}_{3}+\mathrm{NH}_{4}\right)$ to Dendranthema x grandiflorum (Ramat.) Kitamura 'Sunny Mandalay' plants seven (7/day) or 14 times/ day (14/day). These plants were compared to a $20 \mathrm{~mm} \mathrm{~N}$ control in which nutrient solution was applied when the soil moisture tension reached $30 \mathrm{kPa}$. Plants with 7/day had significant quadratic relationships for height, width, and dry weight, with the lowest responses at the low nutrient concentration. With 14/day, height and dry weight did not differ, although width did increase linearly with nutrient solution concentration. However, linear regression slopes for all three variables were much lower with 1Vday than with 7/day. At midcrop in both experiments, significant regression curves indicated that the lower concentrations of nutrient solution resulted in lower tissue $\mathbf{N}$ and K levels; however, slopes of the linear regressions were lower with 14/day than with 7/ day. With 7/day, the water content (percentage) of plants in the schedule-fertilized treatments was higher in plants receiving higher nutrient concentrations, as indicated by the significant linear and quadratic regression curves. With 14/day, the water content was linearly related to solution nutrient concentration, but with a lower slope than with 7/day. These three trends indicate that steady-state nutrition was more closely achieved in a commercial-style substrate with 14/day applications of nutrient solution. These results suggest that plant growth that meets commercial expectations can be achieved at lower soil solution nutrient concentrations than currently applied.
\end{abstract}

Much research using continuous replacement hydroponic systems has established that sustained, ultralow nutrient concentrations in the rhizosphere result in normal plant growth, that is, growth that meets commercial expectations (GrowerTalks, 1989). Low, sustained nutrient levels are achieved by continuous nutrient replacement and extensive stirring of the soil solution.

Williams (1961) found that barley (Hordeum vulgare L.) grew well in a solution culture system at K concentrations approaching $13 \mu \mathrm{M}$. Asher and Ozanne (1967) grew 14 plant species in continuous replacement hydroponics at $\mathrm{K}$ levels ranging from 1.2 to

Received for publication 22 Aug. 1991. Accepted for publication 18 Feb. 1992. From a thesis submitted by K.A.W. in partial fulfillment of the requirements for the MS degree. The research reported in this publication was funded by the North Carolina Agricultural Research Service (NCARS) and Fisons Horticulture. Use of trade names in this publication does not imply endorsement by the NCARS of products named nor criticism of similar ones not mentioned. Appreciation is extended to Yoder Brothers for providing chrysanthemum cuttings. The laboratory assistance of Nancy C. Mingis is gratefully acknowledged. We also thank William H. Swallow for his excellent statistical guidance. The cost of publishing this paper was defrayed in part by the payment of page charges. Under postal regulations, this paper therefore must be hereby marked advertisement solely to indicate this fact.

'Graduate Research Assistant.

${ }^{2}$ Professor.
$1016 \mu \mathrm{M}$. Eight species reached maximum yield at $24 \mu \mathrm{M} \mathrm{K}$ and six at $95 \mu \mathrm{M} \mathrm{K}$.

The effect of ultralow $\mathrm{N}$ concentrations on plant growth in solution culture has also been studied. Clement et al. (1974) found that 7.1 $\mu \mathrm{M} \mathrm{N}$ was adequate for normal ryegrass (Lolium perenne L.) growth. Winsor and Massey (1978) and Massey and Winsor (1980) demonstrated that when the nutrient level was maintained, tomato (Lycopersicon esculentum Mill.) plants grown at $\mathrm{N}$ concentrations ranging from 710 to $22,900 \mu \mathrm{M} \mathrm{N} \mathrm{O}-\mathrm{N}$ showed no significant differences in yield. Elliot and Nelson (1983) successfully grew chrysanthemums in a flowing solution culture system with $30 \mu \mathrm{MN}$.

Ingestad and Agren (1988) and Ingestad and Lund (1986) have shown that a steady level of nutrient availability, ranging from high to ultralow concentrations (e.g., $34 \mu \mathrm{M}$ $\mathrm{N}$ range), results in steady-state nutrition and growth. A plant in steady-state nutrition and growth has a relative nutrient accumulation rate equal to its relative growth rate; consequently, the internal concentration of the nutrient under control remains constant. This relationship implies that plants of a given species, each grown at a different but steady external concentration of a nutrient, will all yield the same internal nutrient concentration and total growth providing that nutrients are replaced at the rate at which they are removed from the rhizosphere.

The preceding studies involved solution culture with continuous nutrient additions and stirring. However, in a solid root medium culture system, continuous nutrient replacement and extensive stirring of the soil solution are difficult to achieve because it is necessary to space nutrient solution applications sufficiently apart to ensure adequate substrate aeration. Movement of the soil solution in a solid substrate occurs only when water or nutrient solution is applied. We assume, as proven with continuous replacement hydroponics, that plants will produce normal growth at ultralow nutrient concentrations in a solid substrate if nutrient levels are equally well sustained and problems of medium aeration overcome. The question, then, becomes whether it is possible to sufficiently establish and sustain low nutrient concentrations in a solid root medium and support normal plant growth.

If this concept is proven, new slow-release nutrient sources capable of sustaining ultralow nutrient levels within the rhizosphere could be designed. Such low root-medium nutrient concentrations would reduce nutrient losses-in greenhouse effluent and thus make it possible to comply with governmental antipollution regulations without the adoption of expensive, closed cultural systems such as ebb-and-flow. These new slowrelease sources would need to be finely dispersed through the root medium such that nutrient release occurs within the rhizosphere of most roots. Current slow-release fertilizers, due to large particle size, are not sufficiently dispersed throughout the medium to maintain contact with each rhizosphere through the drying cycle.

The objective of this study was to determine if low nutrient concentrations can be adequately maintained in a commercial-style root medium and result in commercially acceptable growth of chrysanthemums.

Two experiments were conducted with five treatments common to both. A nutrient formulation consisting of the molar ratio 1 $\mathrm{N} \mathrm{H}_{4} \mathrm{H}_{2} \mathrm{PO}_{4}: 3 \mathrm{KNO}_{3}: 3 \mathrm{NH}_{4} \mathrm{~N} \mathrm{O}_{3}$ was applied to all treatments. An automated system was used to deliver the above formulation at $\mathrm{N}$ concentrations of $0.5,1.0,4.0$, or 20.0 mм to pot chrysanthemum 'Sunny Mandalay' plants in 10-cm standard, round, green plastic pots (413-ml root medium volume and $7.5 \mathrm{~cm}$ depth). The concentrations of $\mathrm{P}$ and $\mathrm{K}$ differed similarly. These four treatments are referred to as "schedule-fertilized" because solution application was controlled by the time clock. The frequency of nutrient application was 7 times/day in Expt. 1 and 14 times/day in Expt. 2. The volume of solution applied to each pot at each application was 200 to $225 \mathrm{ml}$. Times of application in Expt. 1 were: 0100, 0700, 1000, 1200, 1400, 1600, and 1900 HR and in Expt. 2: 0100, 0400, 0700, 0830, 1000, 1100, 1200, 1300, $1400,1500,1600,1730,1900$, and 2200 HR. The root medium in these four treatments consisted of equal volumes of sphag num peat and perlite, both screened at 0.16 $\mathrm{cm}$ to remove dust-like particles with colloidal properties and to maximize medium aeration.

A fifth treatment in each experiment con- 
Table 1. End-crop ${ }^{2}$ height, width, dry weight, and water content (percent) of chrysanthemum plants with 7 (Expt. 1) or 14 (Expt. 2) nutrient applications/day.

\begin{tabular}{|c|c|c|c|c|}
\hline $\begin{array}{l}\mathrm{N} \\
\text { (mM) }\end{array}$ & $\begin{array}{c}\mathrm{Ht} \\
(\mathrm{cm})\end{array}$ & $\begin{array}{l}\text { Width } \\
\text { (cm) }\end{array}$ & $\begin{array}{c}\text { Dry wt } \\
\text { (g) }\end{array}$ & $\begin{array}{l}\mathrm{H}_{2} \mathrm{O} \\
(\%)\end{array}$ \\
\hline \multicolumn{5}{|c|}{ 7/day (Expt. 1) } \\
\hline 0.5 & 20.7 & 20.5 & 5.2 & 88.5 \\
\hline 1.0 & 21.3 & 23.9 & 6.5 & 89.3 \\
\hline 4.0 & 23.1 & 29.8 & 9.3 & 91.0 \\
\hline 20.0 & 24.2 & 34.3 & 9.4 & 92.0 \\
\hline \multicolumn{5}{|c|}{ Linear (Lin) equation ${ }^{y}$} \\
\hline Lin & 0.001 & 0.001 & 0.001 & 0.001 \\
\hline $\mathrm{m}^{\mathrm{x}}$ & 0.15 & 0.58 & 0.16 & 0.15 \\
\hline$r^{2}$ & 0.51 & 0.69 & 0.47 & 0.70 \\
\hline \multicolumn{5}{|c|}{ Quadratic (Quad) equation } \\
\hline Lin & 0.002 & 0.001 & 0.001 & 0.001 \\
\hline Quad & 0.010 & 0.001 & 0.001 & 0.001 \\
\hline$R^{2}$ & 0.68 & 0.88 & 0.92 & 0.95 \\
\hline $20.0^{\mathrm{w}}$ & 19.8 & 24.5 & 6.7 & 90.1 \\
\hline $\mathrm{LSD}^{\mathrm{v}}$ & 1.4 & 2.5 & 0.7 & 0.6 \\
\hline \multicolumn{5}{|c|}{ 14/day (Expt. 2) } \\
\hline 0.5 & 22.9 & 31.2 & 15.3 & 91.6 \\
\hline 1.0 & 22.9 & 31.4 & 14.1 & 91.6 \\
\hline 4.0 & 24.0 & 33.1 & 16.5 & 91.9 \\
\hline 20.0 & 22.8 & 36.1 & 16.1 & 92.3 \\
\hline \multicolumn{5}{|c|}{ Linear equation $y$} \\
\hline Lin & 0.727 & 0.010 & 0.471 & 0.011 \\
\hline $\mathrm{m}^{\mathrm{x}}$ & -0.02 & 0.24 & 0.06 & 0.04 \\
\hline$r^{2}$ & 0.01 & 0.31 & 0.03 & 0.31 \\
\hline \multicolumn{5}{|c|}{ Quadratic equation } \\
\hline Lin & 0.205 & 0.352 & 0.309 & 0.437 \\
\hline Quad & 0.186 & 0.561 & 0.350 & 0.667 \\
\hline$R^{2}$ & 0.11 & 0.33 & 0.08 & 0.31 \\
\hline $20.0^{\mathrm{w}}$ & 17.6 & 26.9 & 9.2 & 90.0 \\
\hline LSD $^{\mathbf{V}}$ & 1.9 & 3.7 & 3.0 & 1.3 \\
\hline
\end{tabular}

${ }^{2}$ End-crop at week eight in Expt. 1 and week 10 in Expt. 2.

'Level of significance for linear and quadratic terms and coefficients of determination for linear and quadratic equations.

${ }^{\mathrm{x}}$ Slope of linear equation.

"Control fertilized when soil moisture tension (SMT) reached $30 \mathrm{kPa}$.

LSD $(\alpha=0.05)$ for comparisons against the control.

sisted of the same nutrient formulation at a concentration of $20 \mathrm{~mm} \mathrm{~N}$ applied only when the root medium in five pots diminished to a weight indicative of a soil moisture tension (SMT) of $30 \mathrm{kPa}$ (as determined from a moisture-release curve for the root medium and corrected for plant weight at the start of each water cycle). Nutrient solution was handapplied to provide $15 \%$ excess fluid for leaching. Root medium used in this treatment consisted of equal unscreened volumes of sphagnum peat and coarse vermiculite (Terra-lite, grade 2, Grace-Sierra Co., Fogelsville, Pa.). The medium was not screened, and vermiculite was substituted for perlite so that a representative commercial substrate would be used as the control.

Root media in all treatments were amended with the following materials and rates per liter: 6.0 g dolomitic limestone, 1.8 g $20 \%$ superphosphate, and $0.074 \mathrm{~g}$ FTE-555 micronutrient mix (Frit Industries, Ozark, Ala.).

Procedures common to both experiments were as follows. One rooted chrysanthemum cutting was planted in each pot and pots were spaced $20 \times 23 \mathrm{~cm}$ on a greenhouse bench. A guard row was placed around the perimeter of each experiment. The design of both experiments was a split plot with completely random main plots so that there were five two-pot replicates of each treatment. One pot in each replicate was harvested at midcrop mined by averaging two measurements taken at right angles. Dry weight (dried for $48 \mathrm{~h}$ at $70 \mathrm{C}$ ) of the total aboveground portion of the plant was measured at mid- and end-crop harvest.

Total aboveground plant tissue was rinsed under warm tap water, washed for $30 \mathrm{sec}$ in $0.2 \mathrm{~N} \mathrm{HCl}$, rinsed under warm tap water, and finally rinsed for $30 \mathrm{sec}$ in distilled water. The samples were dried at $70 \mathrm{C}$ and then ground in a stainless steel Wiley mill to a particle size $51 \mathrm{~mm}$ (20-mesh screen). Tissue used in the analysis of $\mathrm{P}, \mathrm{K}, \mathrm{Ca}$, and $\mathrm{Mg}$ was dry-ashed at 500C. After an addition of $6 \mathrm{~N} \mathrm{HCl}$, the tissue was heated to dryness over a boiling water bath and then dissolved in $0.5 \mathrm{~N} \mathrm{HCI}$. Total $\mathrm{N}$ was determined by a semi micro-Kjeldahl procedure. Salicylic acid was added to the sulfuric acid as a pretreatment to digestion to aid in the reduction of nitrate (Eastin, 1978). $\mathrm{PO}_{4}-\mathrm{P}$ was determined by calorimetric analysis (Chapman and Pratt, 1961) using a UVMS spectrophotometer (Perkin-Elmer, Norwalk, Conn.). Potassium, $\mathrm{Ca}$, and $\mathrm{Mg}$ were analyzed by atomic absorption spectroscopy.

Initial $\mathrm{pH}$ and electrical conductivity (EC) of the root media were measured. Ten pots of each medium were thoroughly watered, allowed to drain for $24 \mathrm{~h}$, watered again, allowed to drain for $1 \mathrm{~h}$, and then sampled. These root media samples as well as samples collected at mid- and end-crop harvests were dried at 70C. Distilled water was added to the root medium, 2:1 (v/v), stirred, allowed to stand for $1.5 \mathrm{~h}$, and the extract decanted. This extract was used for $\mathrm{pH}$ and $\mathrm{EC}$ analyses.

When nutrient solution was applied to the schedule-fertilized plants 7/day (Expt. 1), significant quadratic relationships (Table 1) were found for height, width, and dry weight. In each case, lower solution nutrient concentrations resulted in lower plant response than the higher concentrations, but the response curve was flattening out at the higher concentrations (Table 1). Plants schedulefertilized with $20 \mathrm{~mm} \mathrm{~N}$ were larger in all growth characteristics than those SMT-fertilized with $20 \mathrm{~mm} \mathrm{~N}$, with these control plants being most similar to plants schedulefertilized at the $1 \mathrm{~mm} \mathrm{~N}$ level. Thus, nutrient solution applied 7/day produced commercially acceptable plants that were superior to the $20 \mathrm{~mm}$ N SMT-fertilized control plants.

Significant regression curves indicated that the lower concentrations of $\mathrm{N}, \mathrm{P}$, and $\mathrm{K}$ in solution resulted in lower tissue $\mathrm{N}, \mathrm{P}$, and $\mathrm{K}$ levels in the schedule-fertilized plants at midcrop (Table 2). Shortages of nutrients apparently occurred between nutrient applications and were most severe in plants receiving the lowest nutrient concentrations. Steady-state nutrition was not achieved. Higher tissue concentrations of $\mathrm{Ca}$ and $\mathrm{Mg}$ associated with application of lower nutrient solution concentration of $\mathrm{N}, \mathrm{P}$, and $\mathrm{K}$ were likely a consequence of lower antagonistic pressure from NH, and $\mathrm{K}$ (Marschner, 1986) and/or a concentrating effect of decreasing shoot dry weight.

When nutrient solution was applied 14/ 
Table 2. Midcrop (5 weeks) nutrient concentrations of total aboveground chrysanthemum tissue with 7 (Expt. 1) or 14 (Expt. 2) nutrient applications/day.

\begin{tabular}{|c|c|c|c|c|c|}
\hline \multirow{2}{*}{$\begin{array}{l}\mathbf{N} \\
(\mathrm{mM})\end{array}$} & \multicolumn{5}{|c|}{ Dry wt (\%) } \\
\hline & $\mathbf{N}$ & $\mathbf{P}$ & $\mathbf{K}$ & $\mathrm{Ca}$ & $\mathrm{Mg}$ \\
\hline \multicolumn{6}{|c|}{ 7/day (Expt. 1) } \\
\hline 0.5 & 5.15 & 0.62 & 5.73 & 1.61 & 0.50 \\
\hline 1.0 & 6.19 & 0.67 & 6.66 & 1.59 & 0.46 \\
\hline 4.0 & 6.91 & 0.80 & 7.29 & 1.58 & 0.39 \\
\hline 20.0 & 8.08 & 1.03 & 7.74 & 0.95 & 0.26 \\
\hline \multicolumn{6}{|c|}{ Linear (Lin) equation ${ }^{2}$} \\
\hline Lin & 0.001 & 0.001 & 0.001 & 0.001 & 0.001 \\
\hline $\mathrm{m}^{\mathrm{y}}$ & 0.12 & 0.02 & 0.07 & -0.03 & -0.01 \\
\hline$r^{2}$ & 0.76 & 0.88 & 0.58 & 0.96 & 0.87 \\
\hline \multicolumn{6}{|c|}{ Quadratic (Quad) equation } \\
\hline Lin & 0.001 & 0.001 & 0.001 & 0.984 & 0.001 \\
\hline Quad & 0.001 & 0.001 & 0.001 & 0.005 & 0.001 \\
\hline$R^{2}$ & 0.90 & 0.94 & 0.85 & 0.97 & 0.94 \\
\hline $20.0^{x}$ & 6.64 & 1.09 & 6.83 & 1.39 & 0.60 \\
\hline$L S D^{w}$ & 0.29 & 0.07 & 0.25 & 0.08 & 0.03 \\
\hline \multicolumn{6}{|c|}{ 14/day (Expt. 2) } \\
\hline 0.5 & 5.51 & 0.64 & 6.71 & 1.81 & 0.38 \\
\hline 1.0 & 5.43 & 0.65 & 6.60 & 1.70 & 0.33 \\
\hline 4.0 & 5.96 & 0.75 & 7.26 & 1.39 & 0.27 \\
\hline 20.0 & 7.16 & 0.95 & 7.47 & 0.87 & 0.19 \\
\hline \multicolumn{6}{|c|}{ Linear equation ${ }^{z}$} \\
\hline Lin & 0.001 & 0.001 & 0.003 & 0.001 & 0.001 \\
\hline $\mathrm{m}^{\mathrm{y}}$ & 0.09 & 0.02 & 0.04 & -0.04 & -0.01 \\
\hline$r^{2}$ & 0.92 & 0.91 & 0.40 & 0.89 & 0.78 \\
\hline \multicolumn{6}{|c|}{ Quadratic equation } \\
\hline Lin & 0.001 & 0.001 & 0.007 & 0.001 & 0.001 \\
\hline Quad & 0.083 & 0.007 & 0.021 & 0.001 & 0.001 \\
\hline$R^{2}$ & 0.93 & 0.94 & 0.57 & 0.96 & 0.92 \\
\hline $20.0^{x}$ & 6.56 & 1.25 & 7.42 & 1.09 & 0.51 \\
\hline $\operatorname{LSD}^{\mathbf{w}}$ & 0.23 & 0.06 & 0.50 & 0.09 & 0.03 \\
\hline
\end{tabular}

${ }^{2}$ Level of significance for linear and quadratic terms and coefficients of determination for linear and quadratic equations.

${ }^{y}$ Slope of linear equation.

${ }^{x}$ Control fertilized when soil moisture tension (SMT) reached $30 \mathrm{kPa}$

"LSD $(\alpha=0.05)$ for comparisons against the control.

Table 3. Amount $\mathrm{N}$ applied per day to schedule-fertilized chrysanthemum plants ${ }^{2}$ with 7 (Expt. 1) or 14 (Expt. 2) nutrient applications/day.

\begin{tabular}{lcccr}
\hline \hline \multirow{2}{*}{$\begin{array}{l}\text { No. times } \\
\text { applied/day }\end{array}$} & $\mathbf{4}$ & $\mathrm{N}(\mathrm{mM})$ & 20 \\
\cline { 2 - 5 } & $\mathbf{0 . 5}$ & 1 & 4 & 397 \\
7 & 9.9 & 19.9 & 159 & 794 \\
14 & 19.9 & 39.7 & 159 & 20.4 \\
${ }^{2} \mathrm{~N}$ applied per day $(\mathrm{mg})=$ container capacity $(\mathrm{ml}) \times \mathrm{mg} \mathrm{N} / \mathrm{ml}$ in fertilizer $\times$ no. applications/day.
\end{tabular}

day (Expt. 2), height and dry weight of plants that received the four schedule-fertilized treatments did not differ; neither linear nor quadratic models showed any significant change in these responses with reduced solution nutrient concentration (Table 1). While these results imply that steady-state nutrition was achieved, the significant linear increase in plant width with increased concentration suggests that steady-state nutrition was not achieved in all schedule-fertilized treatments. However, the much lower linear regression slopes for plant height, width, and dry weight in the 14/day experiment show that steady-state nutrition was more nearly met in that experiment than in the 7/day experiment. The $20 \mathrm{~mm}$ N EMT-fertilized control plants were significantly smaller than plants schedule-fertilized at all concentrations tested.

An important factor to be considered in interpreting the results of these studies is not the $\mathrm{N}$ concentration applied as such, but in- dry weight, showing that at midcrop, plants were gaining $372 \mathrm{mg}$ dry matter/day and at end-crop $817 \mathrm{mg}$ dry matter/day. An estimate of $\mathrm{N}$ uptake per day was made by multiplying $4 \% \mathrm{~N}$ by growth per day, which suggests that the plants required $14.9 \mathrm{mg} \mathrm{N} /$ day at midcrop and $32.7 \mathrm{mg} \mathrm{N} /$ day at endcrop for optimal growth. A comparison of these latter two values with the milligrams $\mathrm{N}$ actually applied per day throughout the experiments (Table 3) suggests that enough $\mathrm{N}$ was being applied at midcrop to all plants except those with $0.5 \mathrm{~mm} \mathrm{~N}$ under $7 /$ day, and by end-crop to all plants except the 0.5 and $0.1 \mathrm{~mm} \mathrm{~N}$ plants under $7 /$ day and the $0.5 \mathrm{~mm} \mathrm{~N}$ plants under 14/day. Plants in these treatments would not be expected to match the growth of the $20 \mathrm{~mm} \mathrm{~N}$ schedulefertilized plants and undoubtedly accounted for the significant regressions. Further, this would explain how plants in the 14/day experiment more nearly fit a steady-state nutrition situation. Treatments with higher nutrient concentrations may also have resulted in-lower growth and tissue nutrient levels due to $<100 \%$ nutrient uptake efficiency. It is possible that even the lowest nutrient levels used in this study would support steady-state nutrition if more frequent additions were made.

The tissue N, P, and $\mathrm{K}$ levels of the schedule-fertilized plants were highest with the 20 mM N nutrient regime and lowest in the 0.5 and $1 \mathrm{~mm} \mathrm{~N}$ regimes; significant quadratic relationships were observed (Table 2). Slopes of the linear regressions for $\mathrm{N}$ and $\mathrm{K}$ were smaller with 14/day than with $7 /$ day. These results indicate again that steady-state nutrition was not achieved, but that it was more nearly achieved with 14/day than with $7 /$ day. The total aboveground plant tissue levels of all nutrients were relatively high, which indicates luxury nutrient consumption. As with 7/day, antagonisms of $\mathrm{Ca}$ and $\mathrm{Mg}$ uptake by $\mathrm{N} \mathrm{H}_{4}$ and $\mathrm{K}$ were suggested by the tissue analyses.

As the concentration of nutrients in plant tissue increases, the osmotic potential of that tissue decreases, and the ability of the plant to absorb water increases (Nobel, 1983). With $7 /$ day, the percentage of water in plants in the schedule-fertilized treatments was higher in the plants receiving higher nutrient concentrations, as suggested by the significant linear and quadratic regression curves (Table 1 ). With $14 /$ day, the percentage of water was linearly related to solution nutrient concentration, but with a smaller slope than with 7/ day. This further indicates that steady-state nutrition was more nearly achieved with 14/ day.

The $20 \mathrm{~mm}$ N SMT-fertilized control possibly resulted in poorer growth than the schedule-fertilized plants in both experiments for a combination of reasons. First, a greater quantity of water was available to schedule-fertilized plants, which may have attributed to the better growth of plants in this system. The data for water content (percent) tend to support this idea, with significant differences found between the $20 \mathrm{~mm}$ $\mathrm{N}$ schedule-fertilized treatment and SMT- 
Table 4. Root medium pH and electrical conductivity (EC) with 7 (Expt. 1) or 14 (Expt. 2) nutrient applications/day.

\begin{tabular}{|c|c|c|c|c|}
\hline \multirow[b]{2}{*}{$\begin{array}{l}\mathrm{N} \\
(\mathrm{mM})\end{array}$} & \multicolumn{2}{|c|}{ 7/day (Expt. 1) } & \multicolumn{2}{|c|}{ 14/day (Expt. 2) } \\
\hline & $\mathrm{pH}$ & $\begin{array}{c}\mathrm{EC}^{2} \\
\text { (mmho) }\end{array}$ & $\mathrm{pH}$ & $\begin{array}{c}\mathrm{EC} \\
(\mathrm{mmho})\end{array}$ \\
\hline & \multicolumn{2}{|c|}{ Initial } & \multicolumn{2}{|c|}{ Initial } \\
\hline Trt mix & 4.98 & 0.56 & 5.23 & 0.54 \\
\hline \multirow[t]{2}{*}{ SMT cont ${ }^{x}$} & 5.47 & 0.62 & 5.24 & 0.78 \\
\hline & \multicolumn{2}{|c|}{ Midcrop (wk 5) } & \multicolumn{2}{|c|}{ Midcrop (wk 5) } \\
\hline 0.5 & 5.99 & 0.33 & 6.43 & 0.24 \\
\hline 1.0 & 5.90 & 0.33 & 6.23 & 0.28 \\
\hline 4.0 & 5.76 & 0.46 & 6.03 & 0.32 \\
\hline 20.0 & 5.48 & 1.11 & 5.99 & 0.42 \\
\hline \multicolumn{5}{|c|}{ Linear (Lin) equationw } \\
\hline Lin & 0.001 & 0.001 & 0.001 & 0.001 \\
\hline $\mathrm{m}^{\mathbf{v}}$ & -0.02 & 0.04 & -0.02 & 0.01 \\
\hline$r^{2}$ & 0.66 & 0.95 & 0.45 & 0.48 \\
\hline $20.0^{x}$ & 5.23 & 1.31 & 5.22 & 1.62 \\
\hline \multirow[t]{2}{*}{ LSD $^{\mathbf{u}}$} & 0.19 & 0.18 & 0.11 & 0.28 \\
\hline & \multicolumn{2}{|c|}{ End-crop (wk 8) } & \multicolumn{2}{|c|}{ End-crop $(w k 10)$} \\
\hline 0.5 & 6.24 & 0.42 & 5.90 & 0.99 \\
\hline 1.0 & 6.31 & 0.48 & 5.98 & 0.77 \\
\hline 4.0 & 6.12 & 0.56 & 6.00 & 0.48 \\
\hline 20.0 & 5.66 & 0.93 & 6.33 & 0.60 \\
\hline \multicolumn{5}{|c|}{ Linear equation" } \\
\hline Lin & 0.001 & 0.001 & 0.001 & 0.087 \\
\hline $\mathrm{m}^{\mathrm{v}}$ & -0.03 & 0.02 & 0.02 & -0.01 \\
\hline$r^{2}$ & 0.88 & 0.88 & 0.56 & 0.15 \\
\hline $20.0^{x}$ & 5.23 & 1.56 & 5.25 & 3.12 \\
\hline $\mathrm{LSD}^{\mathrm{u}}$ & 0.12 & 0.24 & 0.22 & 0.42 \\
\hline
\end{tabular}

${ }^{\mathrm{E}} \mathrm{EC}$ of $0.5,1,4$, and $20 \mathrm{~mm} \mathrm{~N}$ nutrient solutions were $0.20,0.25,0.53$, and 2.00 mhos, respectively. ${ }^{y}$ Schedule-fertilized treatments.

${ }^{*}$ Control fertilized when soil moisture tension (SMT) reached $30 \mathrm{kPa}$.

"Level of significance for linear terms and coefficients of determinaton for linear equations.

"Slope of linear equation.

"LSD $(\mathrm{a}=0.05)$ for comparisons against the control.

fertilized control in both experiments (Table 1). In addition, $15 \%$ leaching was not sufficient and possibly resulted in salt buildup that suppressed plant growth. All EC values were at acceptable levels except for that of the SMT-fertilized control in Expt. 2, which had an EC level of $3.12 \mathrm{mmhos} \cdot \mathrm{cm}^{-1}$ at endcrop harvest (Table 4).

Except at end-crop harvest of Expt. 2 (14/ day), $\mathrm{pH}$ was highest in medium to which the lowest nutrient concentration $(0.5 \mathrm{~mm})$ had been applied (Table 4). This relationship suggests that an excess of cation uptake over anions resulted in increased acidification of the root medium at the higher fertilizer concentrations (Marscher, 1986). Because the providing low, steady soil solution nutrient concentrations throughout the rhizosphere within a container.

\section{Literature Cited}

Asher, C.J. and P.G. Ozanne. 1967. Growth and potassium content of plants in solution cultures maintained at constant potassium concentrations. Soil Sci. 103:155-161.

Chapman, H.D. and P.F. Pratt. 1961. Methods of analysis for soils, plants, and waters. Univ. of Calif.. Div. Agr. Sci. Berkley.

Clement C.R., M.J. Hopper, R.J. Canaway, and L. Jones. 1974. A system for measuring the uptake of ions by plants from flowing solutions of controlled composition. J. Expt. Bot. 24:8199.

Eastin, E.F. 1978. Total nitrogen determination for plant material containing nitrate. Anal. Biochem. 85:591-594.

Elliott, G.C. and P.V. Nelson. 1983. Relationships among nitrogen accumulation, nitrogen assimilation, and plant growth in chrysanthemums. Physiol. Plant. 57:250-259.

Growertalks. 1989. Produce Marketing Association recommended grades and standards for pot plants. GrowerTalks. 53(4):14-16.

Ingestad, T. and G.I. Agren. 1988. Nutrient uptake and allocation at steady-state nutrition. Physiol. Plant. 72:450-459.

Ingestad, T. and A.B. Lund. 1986. Theory and techniques for steady state mineral nutrition and growth of plants. Scandinavian. J. For. Res. 1:439-453.

Kuehny, J.S. 1988. The influence of supplemental carbon dioxide and irradiance on growth and nutrient accumulation of Chrysanthemum. MS Thesis, North Carolina State Univ.. Raleigh.

Lunt, O.R., A.M. Kofranek, and J.J. berth. 1964. Some critical nutrient levels in Chrysanthemum X morifolium, cultivar Good News, p. 398-413. In: C. Bould, P. Prevot, and J.R. Magness, (eds.). Plant analysis and fertilizer problems. IV. W.F. Humphrey, Geneva, N.Y.

Marschner, H. 1986. Mineral nutrition of higher plants. Academic, London. p. 36-38.

Massey, D. and G.W. Winsor. 1980. Some responses of tomatoes to nitrogen in recirculating solutions. Acta Hort. 98:127-137.

Nobel, P.S. 1983. Biophysical plant physiology and ecology. W.H. Freeman, New York. p. 7179.

Widmer, R.E., J.M. Dole, and H.F. Wilkins. 1989. Tissue analysis standards. GrowerTalks 53(4):21. Williams, D.E. 1961. The absorption of potassium as influenced by its concentration in the nutrient medium. Plant \& Soil 15:387-399.

Winsor, G.W. and D.M. Massey. 1978. Some aspects of the nutrition of tomatoes grown in recirculating solution. Acta Hort. 82:121-132. 